\title{
Watercourses and Discourses: Coalmining in the Upper Hunter Valley, New South Wales
}

\author{
Linda Connor, Nick Higginbotham, Sonia Freeman, \\ and Glenn Albrecht \\ University of Newcastle
}

\begin{abstract}
Water is a resource that both unites and divides people in the Upper Hunter Valley of New South Wales, where many communities are facing the prospect of large-scale open-cut coalmining developments on productive mixed use land, or already live in proximity to mines and power stations. This article analyses conflicts over a proposed coal mine at Bickham in the Upper Hunter Valley, by contrasting the various protagonists' discourses of water scarcity, supply, and connectivity. It examines the ways in which the terms of opposition are narrowed to the arena of state and industry supported science and economic development, marginalising other cultural values and environmental ethics that are integral to opponents' discourses. Opponents have achieved some measure of success through contestation of the uncertain science of hydrological modelling, bolstered by the context of drought and increasing public acceptance of climate change science.

Key words: water, Hunter Valley, environment, discourse, mining.
\end{abstract}

The Hunter Region is a place of many cultural landscapes which both produce and are the product of 'the material culture through which human agency is enacted' (Strang 2004: 5). The commonly used terms 'Hunter Region' and 'Hunter Valley', denote a geographical location whose boundaries are defined by the catchment of the Hunter River, with a range of more specific functional definitions associated with various government departments and programs. The Hunter has a long history of habitation: numerous Aboriginal people (Awabakal, Wonnarua, Darkinung, Wolimi, Kamillaroi) thrived in the valley before white settlement and after ancestral beings created the sentient landscape of which humans are a part. These meanings now reside in Aboriginal stories and feelings about the land, and are inscribed in the many places still bearing indigenous names (Albrecht 2000; Newell 2003).

There has been more than 200 years of intensive settler land use with associated major landscape changes, beginning with the early discovery of ample deposits of surface coal, then land-clearing for farming and pastoralism, and continuing today with large-scale industrial activity focused on coal extraction and combustion. Settler cultural landscapes dominate popular and public discourses of place, inscribing Anglo-Celtic place names and naturalising the organisation of the landscape around profitable rural production, legitimising extensive land clearing. Water is valued as a key factor of production, and calculations of profitability revolve around humans' right to exploit the 'natural resources' of the landscape. The cultural landscapes constituted by both Aborigines and multigenerational settlers (of which there are many in the Hunter Valley) involve strong sentiments of custodianship of the land (differently expressed) and feelings of place attachment. 
The coal industry has its own cultural landscape connected with the scientific identification of the strata and seams beneath the surface of the land. This is a rich, dark and wet landscape where locations (not necessarily places) are identified by alphanumeric and geological names. In this landscape, the resources of water and soil and the humans dwelling on the surface might obstruct the cultural value of profitable resource development. For many years, the mining of Hunter coal was done underground, but since the 1970s the subsurface has been transformed by over 500 square kilometres of open-cut mining. Upper Hunter communities north of Muswellbrook have so far escaped open-cut coalmining. Their farming economies have been traditionally based on grazing, viticulture, dairying, river flat cropping and horse studs and their landscape has been seen by insiders and outsiders as 'clean and green'. By contrast, the appearance of much of the neighbouring government areas of Singleton and Muswellbrook has been described in an oft-used phrase: 'like a moonscape' (Connor et al. 2004). Previous research by the authors on the impact of open cut coalmining and power station fallout on the health and well-being of residents in affected areas found considerable distress at the loss of much loved landscapes, degradation of physical amenity (dust, noise) and a sense of powerlessness (Connor et al. 2004; Higginbotham et al. 2006). A new concept, 'solastalgia' was created to more adequately describe the particular form of existential and psychological distress connected to negatively perceived changes to the 'home' environment (Albrecht et al. 2007; Albrecht 2005).

In the face of an increasing number of new mine proposals associated with high coal prices and heavy export demand, there are many issues around the expansion of coalmining that have concerned rural communities in this part of Australia. This article examines the ways in which water has become contested in coalmine developments in one area of the Upper Hunter Valley, Murrurundi, where, for the first time, there is a proposal for an opencut coalmine.

\section{WATER SCARCITY AND ENCROACHMENT OF COALMINING}

Open-cut mining and coal combustion for power generation in the Upper Hunter compete for resources with long-standing rural production, which depends on good water supplies and access to alluvial soils. Traditionally, local farmers have worked out water allocations face-to-face, by methods fine-tuned to the availability of the water in the catchment. However, conflicts about water allocations have been exacerbated in the past five years due to drought conditions. Farmers have adopted drastic measures in response to the drought: subdividing their land, selling off stock, buying in feed, and not planting crops. There is also growing acceptance that climate change is a major threat to primary producers. Some landholders have started to adapt by changing to more water efficient farming practices, and a small (radical!) minority has begun growing native grass for pasture.

Contestation over water has intensified since the NSW government passed the 2000 Water Management Act. This Act signalled a change in government policy on water that effectively split land ownership from water rights, with the latter becoming a tradeable commodity (McCarthy 2006). Water for irrigation and other purposes is now allocated to users on the basis of a graded licensing system. Five classes of water licences were created, with farmers having 'general security' water rights, and power and mining companies having 'high security' status, with commensurate privileges. The highest priority class of water use is 'environmental flows' which are intended to maintain the minimum viability, if not the health, of rivers. These classifications are at odds with the sense of generational connection and custodianship that Aborigines and some long-term farming inhabitants feel towards water sources in their locality.

Many defenders of the Hunter River and its tributaries deplore the fact that the water allocations to all users are well in excess of a sustainable level, and note that this problem in itself is bound to lead to conflict among users. The Hunter-Central Rivers Catchment Man- 
agement Authority is a statutory authority of the NSW government, and is not empowered to take a strong stand in protecting river health beyond some monitoring and palliation that leaves unchallenged the political inequalities among users and the lack of long-term sustainable practices. Water usage in the 'unregulated' (i.e. undammed) tributaries of the Hunter River is managed through a system of Water Users Groups, with mixed results, due mainly to the impacts of the drought and diminishing agreement about allocations. The indigenous inhabitants of the Upper Hunter, despite their recognition through the NSW Local Land Council system, are noticeably absent from Water User Groups.

The contestation over water that is outlined above is probably not dissimilar to the situation in many rural Australian communities confronted with depleted or degraded water supply and increasing government intervention in water management through a host of legislative instruments and quasi-government bodies. North of Muswellbrook, at the top of the catchment of the Hunter River, there is an added ingredient in this already volatile mix: a growing number of open-cut coalmine development proposals. The latest Asian economic boom, particularly in China, has had a down-side for rural residents of the Upper Hunter Valley. The demand for energy resources to fuel the power stations that support China's factories means open-cut coalmines have become a highly profitable prospect for Australian and multinational companies. Analysts declare the mining industry is in a 'supercycle' (CRC Mining 2006), with Australian coking coal prices for 2006-7 around 110\% higher than for 2003-4 (Reserve Bank of Australia 2007).

In conversations with Upper Hunter residents, the words 'China' and 'globalisation' seem to be on everyone's lips. This is perhaps not uncommon in rural Australia, given the producers' high level of integration into global markets. However, there is no longer the happy confluence of interests that once existed when farmers were selling their products to a hungry world. One small landholder in the Upper Hunter expressed concern that such a precious commodity as water was being used to wash export coal:

....and these coal washeries, you know? I mean, what - we wash it so it's not dusty for the Chinese? Let them wash it with their bloody water, sell it to them as it comes out of the bloody thing, you know? If they're going to pay whatever they're paying now for the coal it makes it worth so much to get it out of there, well let them wash it, you know? Why use decent quality water to wash the bloody coal?

During the past 15 years, open cut mines have proliferated in the Upper Hunter. Farms in mining buffer zones were acquired by mines, along with their water licences (Thompson 2006: 5). Drought conditions have exacerbated resentment among Upper Hunter irrigators that under current legislation too many mines are permitted to draw water from rivers. In May 2006, commentators noted that the Hunter Valley coal and power industries owned $42 \%$ of water licences but used 'only a fraction of the amount of water available to them' (McCarthy 2006). However, when the drought intensified in early 2007, at least one mine near Muswellbrook briefly stopped production due to a water shortage, while another placed the workforce on notice of potential stoppage unless rain was forthcoming.

In the context of the current spate of mine proposals, the protests have widened to embrace an environmental activism and environmental justice movement that is attracting increasing numbers of people. In anthropological terms, the political and cultural processes underpinning environmental activism can be understood as a 'whole new discursive regime' in which nature and human agency are brought into relationship in multiple political contexts (Brosius 1999). Diverse groups struggle to define the arena (i.e. sphere of action, relevant knowledge, or scene of conflict) for debates about environmental futures. These issues are explored through an analysis of protests surrounding Bickham Coal Company's bulk sample coal extraction and plans for mining coal near Murrurundi. 


\section{THE BICKHAM COAL COMPANY DEVELOPMENT}

When it became public knowledge in 2002 that a private company, Bickham Coal, was going to submit a proposal for an open-cut coalmine just south of the Upper Hunter Valley town of Murrurundi, concerned residents organised to challenge the development. The proposed open cut is near a small village called Wingen and close to Burning Mountain (a naturally burning coal seam) and the Pages River. Patrice Newell, a local farmer and author, has described the Pages and its history:

For countless thousands of years it was a vital stream for the Wonnarua people. From 1825 they were dispossessed, their river appropriated by the European settlers who came and kept coming, succeeding and failing, trying to make a living and building towns like Murrurundi, Blandford and our little village, Gundy. Old journals suggest that the Murrawin tribe of the Wonnarua, comprising sixteen men, eight women and five children lived right ... where the Pages meets the Isis River (Newell 2003: 2).

The common interest of these opponents is their dependence on the water from the Pages River, and membership of the Pages River Water Users Group. The proposed mine site is located to the east of the New England Highway, in the catchment of the Pages River (a tributary of the Hunter River). It is a small mine, with $\$ 70$ million capital investment, 22 year mine life and maximum output of 2.5 megatonnes per annum (NSW Department of Planning [NSW DP] 2005: 2). The Pages River is described as having 'high water resource values and associated high ecosystem values,' as well as important 'refuge values'. It flows through the Cameron Gorge Nature Reserve, which contains 'the last remnant vegetation of its type in the Hunter Valley' (NSW DP 2005: 3). The mine will also be close to the Burning Mountain Nature Reserve, which is the only naturally occurring burning coal seam in Australia, and one of only three in the world (NSW DP 2005: 76).

The debate about the water impacts from the Bickham mine was framed by concerns about continuing drought in the Upper Hunter. When the Bickham project was first mooted in 2002, a long dry spell along with high demand for water resources from a variety of users fuelled fears among residents at nearby Murrurundi that mining in the area 'would make even greater demands on the local water system' (Peatling 2002). In 2003, the continuing dry conditions led to outrage by local 'dissenters' that 'in the middle of a drought' the company was going to use the water 'for dust suppression' (Australian Broadcasting Corporation [ABC] Online 2003, 19 September). At the end of 2004, the first stage (Level 1) of increasingly severe restrictions on water irrigation and usage were in force because of the low level of water in aquifers. In response to protests by Upper Hunter residents and irrigators, the Department of Natural Resources denied it was 'being irresponsible in allowing a mining company to use up to 40 megalitres of water over the next two years in the middle of a drought' (ABC Premium News 2004, February 16). By the middle of 2006, the Pages River had 'stopped flowing' and Murrurundi had been placed on more stringent Level 2 restrictions (Herald 2006, 27 May), a situation that by January 2007 had been raised to Level 4 restrictions until further notice (Upper Hunter Shire Council 2007).

One of the main reasons community and environmental activists oppose the Bickham open cut mine proposal is their belief that coalmining operations would extract water 'from two bores drilled into aquifers beneath the river bed' (Peatling 2002), thus damaging flow in the nearby waterways. The possibility of this connectivity has become a key element of the protest against the mine development. Initially, the Bickham Coal Chief Executive responded to community concerns about the health of the river with public statements that strained credulity, such as: 'Rather than just taking that water it will be re-injected back into the aquifer to end up back where it came from' (Peatling 2002). 
In mid-2002, Bickham Coal Company submitted an application to the NSW Department of Mineral Resources (DMR) to extract a 'bulk sample' of 25,000 tonnes of coal from a property about $10 \mathrm{kms}$ south of Murrurundi. Bulk samples are conducted using mining equipment to dig up a designated area to gather material to 'test the mineral bearing qualities of the land' (cited in NSW DP 2005: 11). This sampling is undertaken to determine whether a full-scale coalmining operation would be viable. However, under the NSW Mining Act (1992) bulk samples are classified as 'prospecting' or 'valid exploration' not 'mining'. Community groups opposed to mines regard the rationale for bulk samples with suspicion, asserting that they are really a 'foot in the door' for a company wishing to mine in a new area.

In response to the application, the newly formed 'Bickham Coal-Mine Action Group' [BCAG] met in Murrurundi and has conducted a sustained campaign against the mine. This group is comprised mainly of owners of rural farming or grazing properties that are adjacent to the proposed mine and/or will draw water from the same sources. Some members are descendents of colonial settlers and live in inherited homesteads; whilst others are relative newcomers from the city. Several members are influential in the media and arts communities, including the Australian Broadcasting Corporation broadcaster Phillip Adams, and farmer and author Patrice Newell.

Bickham Coal's first environmental impact assessment (Review of Environmental Factors,) submitted in October 2002, was rejected by community members. Community input was via a consultative committee, and regular public meetings held throughout 2002, as well as by formal submissions to the Review. In November, the Minister directed the company to provide further studies, including the provision of a Water Management Plan, and extended community consultation (NSW DMR 2004: 4). Following the submission of an Amended Review of Environmental Factors by the company in September 2003, the NSW Minister for Mineral Resources announced 'an investigation into the sustainability of any proposals' (Herald 2004, January 20). There were numerous submissions to this investigation, highlighting a range of contrasting views on water impacts. This culminated in the Department issuing a 2004 Assessment Report: Review of Environmental Factors relating to the Bickham Coal Company's mine proposal (NSW DMR 2004). Meanwhile, on the basis of the submissions and the conclusions of the report, the Minister granted approval for a 'bulk sample' in January 2004. The submissions that were cited in the Assessment Report were notable for their varying interpretations of the science that informed the report. Such variation in interpretations is possible because of the inherent uncertainty in hydrological modelling. No amount of drilling and test holes will determine with absolute certainty the way water moves underground (past, present and future). However, the private consultants (scientists) doing the modelling have to present their findings to their employer (The Bickham Coal Company) as if there was no uncertainty and that the outcomes of mining will be unambiguous. Those opposing the mine have to counter-argue that the science is weak and that the modelling is misleading, a task that is very difficult for non-specialists.

\section{CONTESTING STATE-SPONSORED SCIENCE}

State government departments whose submissions were cited in the Assessment Report tended to minimise the negative environmental impacts of the proposed bulk sample in proportion to the centrality of mining to their departmental interests. The Department of Primary Industries (Minerals) was most sanguine, with the Minister cited in the report: 'Results of hydrological studies into the Pages River and surrounding groundwater aquifers' indicate that activity associated with 'surface disturbance' due to the bulk sample 'would be unlikely to significantly affect the environment' (NSW Department of Primary Industries - Minerals, 2004). However, the Department did concede that proceeding with the bulk sample would require 'dewatering' of groundwater from licensed boreholes adjacent to the excava- 
tion which would be monitored using a 'range of environmental monitoring activity, including monitoring of groundwater and surface water' within the exploration licence area (NSW DMR 2004: 5).

The NSW Department of Infrastructure, Planning and Natural Resources (DIPNA) also took a positive view, asserting that the bulk sample 'was likely to have minor impacts on the Pages River' and that the operation would result in 'localised depressurisation of the aquifer and gradient reversal of local groundwaters'. It was considered that the 'short life span' of the bulk sample operations 'would result in relatively minor impacts on adjacent ground and surface waters' (NSW DMR 2004: 12). The discourse of 'minor' or 'minimal' impacts was echoed in the submission of the Department of Environment and Conservation (National Parks and Wildlife Service), which advised that, 'additional studies' on groundwater and surface water had revealed 'minimal potential impacts on water quality and quantity favourable to the protection of the Cameron Gorge Nature Reserve' downstream of the bulk sample. Furthermore, it was considered 'unlikely' that the bulk sample would have a 'substantial detrimental impact on natural or cultural heritage values' (NSW DMR 2004: 14).

The adequacy of environmental modelling, and the independence of the interpretation of those models by industry and state government regulators, was questioned in various ways by locally based groups, environmentalists and local government. The Murrurundi Shire Council (now amalgamated into the Upper Hunter Shire Council) considered water impacts to be a 'primary concern' and called for a 'significant level of monitoring during the proposed activity', particularly because there were differing estimations in the proponent's assessments about the inflow volumes to be dewatered (NSW DMR 2004: 14). Similarly, the Scone Shire Council (now also part of Upper Hunter Shire Council) 'raised concern over the impacts on the Pages River and the groundwater aquifer'; and contested the proponent's environmental impact review by submitting a report by consultants employed by the Council to peer review the proponent's Water Studies (SMEC Australia Pty Ltd.).

The more critical interpretations of the Assessment Report came from more independently situated protagonists, organised around local community and environmental action groups. One of the main reasons community and environmental activists opposed the Bickham bulk sample and subsequent open cut mine proposal, was the belief that coalmining operations would directly connect with, and impact on, the hydrological cycle of the area in profound and unpredictable ways. There was a call for 'further groundwater investigation' from groups like the then Hunter Catchment Management Trust (now Hunter and Central Rivers CMA), a semi-independent state body (NSW DMR 2004: 14). Minewatch, a regional lobby group that acts on behalf of property owners affected by mines, also considered that 'findings on groundwater issues' required 'independent investigation' (NSW DMR 2004: 16).

Alternative scientific expertise was sought to contest the company's models. The Bickham Coal-mine Action Group's submission expressed a strong concern about the 'possible adverse impacts of open cut mining on the Pages River and the surrounding aquifer' (NSW DMR 2004: 16). The group was also concerned about the 'variability of results' and 'monitoring' (NSW DMR 2004: 16). A Greens Party ${ }^{1}$ Member of the NSW Legislative Council objected to the company's Water Management Plan, noting that some of the Bickham coal seams 'intersect' the Pages River which could lead to 'river capture - that is, the river could end up being diverted into the coalmine' (NSW Legislative Council 2003). This was not an uncommon fate of watercourses in the Hunter Valley. It was also the case that a submission by the Wonnarura Nation Aboriginal Corporation and the Wanaruah [sic] Local Aboriginal Land Council contained concerns about, 'The impact on the natural flow of fired rock from the Pages River to Burning Mountain' and 'The impact on cultural heritage values of the WNAC people' (NSW DMR 2004:17).

Environmentalists, local government and Upper Hunter based groups contested the reliability of the proponent's and the government departments' estimations of likely water 
impacts. It should be noted that all this revolved around the bulk sample only - the contestation over the actual mine proposal, if it eventuated, was yet to begin. Community groups often commented that dealing with coal industry proponents and the state government departments that regulate their activities was 'a war of attrition'.

A predictable outcome of the Assessment Report was the Department's requirement for Bickham Coal to consult with other 'stakeholders' about bulk sample impacts, including State government departments, local councils, individuals and special interest groups, including the 'Aboriginal Community' (NSW DMR 2004). Connectivity between mining and the Pages River continued to be denied by the Bickham Project Manager in June 2004, when blasting was in operation for the bulk sample: 'No water will be taken from the river or put back in' (Thompson 2004a). At the end of 2004, scientific testing was used to legitimate the industry view; a Bickham spokesperson stated that 'chemical analysis showed mining the bulk sample had not caused any connectivity between the pit and the river' (Thompson 2004b). Following completion of the bulk sample, Bickham Coal commenced the design and planning for a full-scale open cut mine. The company chose consultants Parsons Brinkerhoff [PB] to conduct 'water resource investigations in and beyond the proposed Bickham site'. They were also given responsibility for community liaison on environmental impacts. PB is a global project management group that has offices in the Upper Hunter. Other projects they have managed include a nuclear storage site in the Northern Territory and freeways and wastewater treatments plants in Victoria (Australian Broadcasting Corporation's Regional News 2006). By February 2007 the water study had still not been completed, and there were no requirements for the bulk sample pit to be rehabilitated until the expiration of water licences in March 2008 (Thompson 2007).

The various criticisms of the scientific evidence endorsed by the government in its report provided enough pressure for the NSW DP to undertake an independent investigation that was broader in scope, which resulted in the release in December 2005 of the report Strategic Assessment of Coalmining Potential in the Upper Hunter Valley. This report concluded that:

The major issues associated with a potential new mine at Bickham are directly related to the river and are of such significance that they need to be separately considered (NSW DP 2005: 2).

It was acknowledged that there was currently 'insufficient information to know whether the groundwater seeping into any future mine at Bickham would be saline and, if so, in what quantities'. Importantly, the report also acknowledged that while there was 'no clear evidence that there is a significant connectivity between the Pages River and the hard rock aquifers at Bickham... Neither is there clear cut evidence yet available that demonstrates there is no significant connection' (NSW DP 2005: 3).

Despite their concerns about the independence of the report, it was hailed as a significant victory by the BCAG and others opposed to the mine, and inspired real hope that the mine would not receive approval. While it did not preclude mining altogether, it certainly raised the bar for the Company in terms of further, more rigorous, environmental assessment work. The most vocal opposition to the mine was from rural producers whose properties had the potential to be affected deleteriously by the as yet unascertained effects on the water supply, and who are also committed to 'precautionary' values of environmental custodianship. The views of residents of Murrurundi and other small towns in the area appear to be mixed, and more difficult to gauge. A substantial number of Murrurundi residents are employed in mining at Muswellbrook. ${ }^{2}$ Many had hopes that the mine would bring more employment in a situation of low opportunity. Residents engaged in commerce hoped for a healthier flow of customers for their businesses.

The Mayor of the Upper Hunter Shire Council was circumspect in his public statements: 
I suppose while there is a feeling of inevitability about coalmining coming to our towns, I'd like to think governments would be a little bit more careful rather than just opening the floodgates...because this is where the tributaries of the Hunter start. If we get it wrong up here we've got a big problem (Quinn 2005).

\section{INDUSTRY, ENVIRONMENTAL AND INDIGENOUS DISCOURSES}

The company continued to make its case for the mine on grounds of scientific legitimacy of the environmental assessments it had undertaken. The Bickham Project Manager stated:

The body of hard scientific knowledge in relation to these issues - gathered before, during and after the extraction of a bulk coal sample - is now far greater as a result of these studies, undertaken by professionals of the highest reputation in the field (Richards 2005).

Furthermore, he questioned the Department of Planning's Draft Upper Hunter Strategic Assessment Report for its 'narrow and flawed interpretation of the facts' relating to connectivity between Pages River and ground water levels (Richards 2005). Industry studies showed that, 'the water levels do move together for much of the time, but there are many occasions when they do not' (Richards 2005). However, equivocal evidence about possible future impacts resulted in the Department of Planning ordering that any future application for an open cut mine within the Pages River Catchment include a groundwater and surface Water Resource Assessment and draft 'life-of-mine' Water Management Plan. The Department also directed that any new coalmine within the Pages River or Dart Brook Catchments, 'be managed so as to maintain the long-term integrity of their streams, alluvial aquifers and ecosystem values' (NSW DP 2005: 5).

The Department of Planning assessment of coalmining potential in the Upper Hunter did not give a clear go ahead for the Bickham open cut or similar proposals. There was acknowledgement of potentially severe environmental repercussions and a number of extra requirements were placed on the company. A Bickham Coal Director stated: 'If we do go ahead we want to base the application on the most extensive and comprehensive range of data on environmental, flora and fauna, heritage, river, landform and ground-water issues collected for an EIS' (Adams M.2004).

Residents initially engaged in tactical struggles to protect place and livelihood were also forced to contest on the grounds of science and its values of objectivity. For example, the Webb, McKeown and Associates Flooding \& Surface Water Assessment (2002) was submitted by the BCAG as an alternative to the environmental assessments being provided by the consultants hired by the mining company. The emergence of climate change as a prominent public concern has also placed locally based struggles in a new context. As well as drawing on site-specific expertise, those opposing coal mine developments are increasingly relying on the global authority of reports such as the Intergovernmental Panel on Climate Change (IPCC) (2007) and the Stern Report on the Economic Impacts of Climate Change (Stern 2006). The growing authority of this climate change science is beginning to reposition industry, government and environmentalists in the debate about water and mining.

The broader ethical and moral frameworks that have been brought into play by climate change debates bolster another approach the opponents have taken, which is to articulate the arguments against the mine (and the expansion of coalmining in general) not only in scientific terms but also in relation to wider social, cultural and ethical values such as democratic association, intergenerational responsibility, custodianship of landscape and family heritage, and the inalienable rights of nature itself.

For rural based protesters, a prominent theme is the preservation of inclusive rather than exclusive use of water. According to a member of the BCAG, the Bickham open cut 
proposal is opposed by a wide variety of interest groups who fear that their share of water from the Pages River will be jeopardised by the mine:

...communities, horse studs and farms downstream were fearful that their river, already stressed by the thirst of townsfolk and farmers, and suffering from an apparently endless drought, would be damaged or destroyed by the venture (Newell 2005).

There was anger that the mining company had refused to attend a Pages River Water Users meeting when the proposal was first mooted in 2002 and was denying 'one central issue in water management - that all water users share the resources' (Newell 2005). Those concerned about conservation, protection of water and landscape and proud of their role as custodians of place also drew on the image of the Upper Hunter landscape as 'pristine' (despite decades of farming activity). Thus, it was reported in the national press that the biggest worry for those concerned about the Bickham bulk sample is the effect on the 'pristine Pages River' (Wynhausen 2003).

Valuing colonial heritage was also a common theme, with one resident likening the actions of the mine equipment to a kind of wild animal whose 'great steel jaws would be ripping into the landscape' close to the graves of pioneering ancestors' families, with the possibility of 'corrupting the aquifers' (Adams P. 2004). A sense of history and place is no better illustrated than in the name of the historic homestead, 'Bickham,' which is 'believed to be a corruption of Beckham meaning place near a brook' (Thompson 2005):

We love the sense of history and people and families who have lived in the rooms before you...It's our family base or whippie' (owner Michaela Malone in Thompson 2005).

Environmentalists and custodian farmers have also articulated the sentience of nature itself and its inalienable right to exist, particularly in the form of the Pages River. Opponents have '...given the Pages a voice at a time when it desperately needs to be heard' (Adams P. 2004). The geological term 'capture' is used to suggest the river is hostage to corrupting influences: 'First we were told of the possibility of the river being captured by the mine. Now there's a probability of the dredging corrupting the aquifers' (Adams P. 2004). Commentators like Philip Adams convey their understanding of the river as a living, breathing entity.

The Pages rises with a tiny waterfall in a Capuchin hermitage $60 \mathrm{~km}$ upstream...does that make it holy water? Certainly its flow was sacred to three downstream villages that depend on it utterly (Adams P. 2004).

These ways of speaking about the river counter industry representative's strategy of relying on knowledge claims based on the assumed 'objectivity' of statistics and scientific modelling.

Young notes that for many Australian indigenous groups water is viewed as having 'agency', personified by the Rainbow or Water Serpent ('Biame') acting upon the surface of the land and interpenetrating beneath the land to connect human and Ancestor beings (Young 2006: 241). Features of the landscape, such as rocks, creeks or water sources, are seen as 'objectifications of the Ancestors - rocks, creeks, sand hills and water sources' (Young 2006: 239). The proposed Bickham mine is situated in what may be termed 'Wonnarua country', which has been described by a descendent of the original inhabitants as ranging from Murrurundi in the Upper Hunter to Newcastle in the Lower Hunter (Veale 2001: 2). The area contains valleys, mountains and water sources which were past fishing and hunting grounds as well as ceremonial sites and camps (Veale 2001: 3). Whilst the Wonnarua have been largely displaced from their traditional lands (Wilson-Miller 2005), it 
is acknowledged by Upper Hunter Shire Council that 'Aboriginal groups in the LGA [local government area] maintain ongoing connections to the land' (Upper Hunter Shire Council 2006: 113-14).

Traditional Wonnarua stories passed down through the generations illustrate the intimate connection between people and the landscape. One such story explains how a Wonnarua maiden, desolate because of the loss of her man in a battle, was turned by Biame into a rocky sandstone outcrop (now known as the 'Wingen Maiden') where her tears ignited the fires of Burning Mountain in the Towarri National Park. Such spiritual connections to water and place are fundamental to current Wonnarua attitudes to the Bickham mine proposal. Their feelings about 'opening the land up' are evident in the following comment from a Wonnarua Land Council member:

I mean, now I can take you to a burial site of six warriors, or a raiding party, that was caught, they'd come into a major camp site and were actually caught, and they were all slaughtered and then... as far as the ceremony, they brought rocks in from completely outside, I mean boulders as big as these tables, to put on top of the burial site to keep the spirits in there, to lock them up, you know, that was their belief, but, I mean once you start opening the land up, where have the spirits gone?

It is well documented that 'systematic surveys' undertaken for mining and other projects in the Upper Hunter have demonstrated a large number of sites which relate to 'Aboriginal heritage', 'especially along creek lines' (Upper Hunter Shire Council 2006: 114). However, as one Wonnarua Land Council member explained, for mining companies only a discrete area adjacent to a mine site is of interest and indigenous 'stakeholders' are limited to assessing just this area:

...when they do the surveys they've only been doing little pockets and they try and get us to do a cultural assessment on this little pocket. Whereas we know there's not the entire area of people within that land system there. And you can't give a cultural assessment on heritage in other areas, I mean, they just don't seem to accept it. It's only what's on their lease area, and that's all they are worried about (Wonnarua Land Council member, 2004).

\section{CONNECTION AND CUSTODIANSHIP}

In the conflict over the Bickham coal mine, connection to, and custodianship of, land and watercourses is a convergent discursive theme (despite different spiritual and epistemological foundations) of both Wonnarua and settler protagonists. For both settlers and Aborigines perceptions of, and connections to, place are formed from past experiences and relationships. Indeed, for some residents the history of the river and the people it nurtured are inextricably linked in time and space. Thus, a prominent member of the BCAG noted:

We forget that we have tens of thousands of years experience living along the Hunter that could be of profound importance to our future which flows from the past like a river gathering strength from its tributaries (Newell 2006).

Past connections with water and the land were key issues raised by indigenous groups opposing the Bickham Bulk Sample. Thus, a submission to the Bickham Bulk Sample Assessment Review of Environmental Factors from the Wonnarura Nation Aboriginal Corporation (WNAC) raised concerns that the Aboriginal site survey for the Bulk Sample only identified 'sites and relics' but did not investigate 'natural and spiritual connections' (NSW DMR 2004: 17). 
In the 19th and 20th centuries, contestation over land and water resources was ongoing between white settlers and indigenous groups (Veale 2001:13). However, both groups had in common an adherence to the value of 'managing the land' or 'custodianship'. For example, one descendent of early settlers was disappointed that the family property had been gazetted as part of Towarri National Park because, 'it wasn't going to be kept as it always had been, fenced and well looked after' (Veale 2001:78). Similarly, a member of the Wonnarua Land Council set out the indigenous attitudes to managing the landscape:

There is no such thing in Aboriginal language as wilderness. You know, this is a managed country. It was managed for bloody centuries. Thousands of millennia, before white man came here, and, the plants and the animals developed around their management... Ah, the burning culture, you know, our trees require the burning culture, to, regenerate, yeah. So, the plants, and some of the animals, are actually designed to handle this burning, of the land, you know, their management. However, the way National Parks are managing it, you know, when they have a fire goes through an area, there's nothing left.

The notion of 'custodianship' was eloquently expressed recently by the President of the Pages River and Tributaries Water Users Association, as justification for opposing the Bickham open-cut mine proposal:

A coalmine doesn't fit with custodianship of our land...we are custodians only of our land. Our purpose in being on that land is to ensure its holistic productive use, and to pass it on in better condition than before (Bennetto 2006).

However, whereas settler views of managing the land fall within what Palsson has called the 'Orientalism' paradigm for understanding human-nature relations, with nature seen as a resource to be utilized for human benefit, the Wonnarua view of managing the environment is closer to the 'communalism' paradigm which emphasises 'generalized reciprocity' and metaphorically expressed intimate relationships (Palsson 1996). Such an emphasis was evident in a Wonnarua Land Council representative's view about the impacts of open-cut mining generally:

I think the destruction of the land both not only goes on a physical, ah, feeling of detachment, but it also is supported by a spiritual detachment, because once the land is tampered with, it's no longer a virgin, if I could put it in that sense. A lot of Aboriginal beliefs all over the country regardless of which mob you come from support that the higher being of Mother Earth being the protector and the provider. And I suppose you've got to look at it in the sense that, would you like your mother gutted, in an operating theatre, and just tossed to one side? The damage that can happen, is never repaired, regardless of the outcome.

\section{IMPACT MANAGEMENT AND ECONOMIC DEVELOPMENT}

For the mining industry and the governments that are major beneficiaries of it, people's land and country is only part of a wider landscape of 'natural resources' that must be managed and developed. David Trigger's analysis (1997) of pro-development ideology in the mining industry highlights the ways in which exploitation of the natural environment is imbued with a higher moral and cultural significance. The land is 'barren' until technology allows it to yield up its wealth (Trigger 1997: 173); minerals are 'recovered' or 'reclaimed' from 'overburden' or waste (Trigger 1997: 170-1). These 'corporate narratives' create a moral vision of wealth production through mining as central to the process of civilisation itself 
(Trigger 1997: 164). For example, to counter evironmentalists' demands for no new mining developments in the Upper Hunter because of the implications for climate change, the peak industry group, NSW Minerals Council, mounted a publicity campaign with the slogan 'Life - brought to you by mining' (McCarthy 2007) to argue that mining is a moral use of land and water. It is emphasised that, in New South Wales, the black coal industry 'supports 67,000 jobs (more than 13,000 directly and more than 54,000 indirectly) and sustains entire communities' (NSW Minerals Council Ltd \& Australian Coal Association 2007); and 'As demand for our coal and other minerals grows, so too do the royalties and taxes payable to governments by the mining companies'(Williams 2007). In addition to economic benefits, campaign advertising claimed that mining makes an 'enormous contribution to our quality of life through products like portable computers, cars, fridges and mobile phones - all brought to you by mining' (NSW Mineral Council Ltd 2007). In a more utilitarian vein, mining and the landscape are often linked using categories such as risk management, profits and resource efficiency. The Chief Executive of the NSW Minerals Council stated recently:

In recent times the NSW coal industry, and in turn the people of NSW, has profited from good times in the global resources market...The challenge that faces governments and industry in developing infrastructure capacity to match demand is that the investment and development require long-term vision and a willingness to take a gamble...(Williams 2007).

However, to more fully understand mining industry discourse requires an exploration of 'the salience of words' which construct meanings, such as: the most appropriate use of the landscape, advancement of technology, and the moral and social standing of mining in the community (known in industry parlance as the 'social licence to operate') (Stutsel 2003).

Whereas indigenous and settler topologies value custodianship or managing the environment, one of the responses of the mining industry to criticism of their activities by environmentalist or community groups is to emphasise their commitment to managing impacts on the environment, including 'water resource impacts (Parsons Brinkerhoff 2006b:1). A Briefing Paper prepared by PB for Bickham Coal focussed on strategies such as the creation of a 'buffer area' to reduce 'potential impacts' on the Pages River (Parsons Brinkerhoff 2006b: 6). Impacts of mining operations on water are to be managed through 'rehabilitated overburden dumps ${ }^{, 4}$ to reduce water runoff, mine water runoff will be directed into 'sediment dams', and a 'system' will be developed to 'isolate 'dirty' water' from 'pits, haul roads and work areas' of the mine which will then be 're-used for dust suppression' (Parsons Brinkerhoff 2006a: 4). The management of impacts takes place within a legislative and regulatory framework that industry and government representatives refer to as the 'licence to pollute'. In NSW, mining companies may seek a relaxation to operate outside environmental protective legislation, notably the Protection of the Environment Administration Act (POEA).

As well as managing impacts, pro-mining discourse is concerned with managing stakeholders. One aim of a community consultation plan outlined by PB for the Bickham project is to 'develop relationships of trust and confidence by listening and responding to community issues, concerns and acting with integrity with what is communicated'. Key strategies include, 'Stakeholder and community group meetings, community information newsletters and website updates, and meetings with individual landholders and interested individuals' (Parsons Brinkerhoff 2006b:9). However, as Brosius argues (1999: 281), in debates concerning the environment, the term 'stakeholder' may be used to limit the range of those who can give legitimate input into disputes over environmental uses such as mining. In 2007 the BCAG was obliged to use a 'Freedom of Information' request to obtain 2003 correspondence from Department of Planning and Minerals Resources officials that revealed official concern that the bulk sample pit could contaminate the Pages River (Thompson 2007). 
Anti-mining protesters who are not locally based are generally denied stakeholder status in government-mandated consultation concerning the Upper Hunter.

Mining industry media releases and reports include the 'valorisation' or 'condemnation' of groups, defining legitimate participants and non-participants, and 'presume to describe the ways in which particular categories of subject affect the environment' (Brosius 1999: 281). Thus, groups calling for a reduction in open-cut coalmining in the Upper Hunter, including prevention of the Bickham open-cut, have been described by an Executive Director of the Australian Coal Association as 'morally vain political movements' whose 'vilification is now causing distress to thousands of working families'(O'Neill 2007). It is stated that the protesters' linking of Hunter Valley coalmining with global warming is 'quixotic', 'one dimensional', 'untenable', 'mistaken' and possibly 'downright dangerous' (O’Neill 2006).

\section{CONCLUSIONS}

As mining intensifies in the Hunter Valley, conflicts about the use and future of critical resources such as water are becoming more frequent. It is becoming increasingly apparent to many that a finite resource such as fresh water is unable to satisfy the principle of plenitude (there is so much of it that nobody needs to fight to get their share). Access to such a resource then becomes a matter of political contestation where state-authorised scientific discourses become integral to the ways in which those with the most power, such as coal and energy industries, achieve their ends, which comes at the expense of smaller, less powerful groups. Our study of the Bickham coalmine proposal highlights how protagonists bring different water discourses into play in the conflicts that developed. Settler and indigenous discourses both emphasise managing land and water but have different rationales. Whereas settlers have historically valued water for human use, indigenous perspectives depict water in terms of reciprocal relationships that link human and ancestral beings over time and space. Both views are animated by concern about place, and emphasise spiritual, historical, religious or other social connections to local waterways and water resources. By contrast, in state and mining industry discourses, water is an essential factor of production in the efficient exploitation of the natural resource and its preparation for sale.

Attempts by mine opponents to broaden the terms of the conflict to encompass the values and ethics of sharing a scarce resource and ensuring future sustainable supply are constantly marginalised by the industry's promotion of 'hard scientific knowledge' in their environmental assessments and consultants' reports; and the government's support of this knowledge is enshrined in their regulatory regimes. Embedded within this scientific discourse are statements that valorise the bulk sample as 'valid exploration activity', and where coal requires 'beneficiation by washing'. The opponents are thus confined to the terms of a contest defined by a conservative science orthodoxy, which overlooks the 'precautionary principle' in favour of commercial interest. Opponents of the Bickham mine have been able to take advantage of the inherent uncertainty of many areas of scientific modelling, particularly hydrological modelling, to mount compelling counter arguments based on science, that they as private citizens have funded. They have also benefited from the increasing acceptance of alternative forms of environmental science that contest the assumptions and facts of state-supported science, and invoke a future of climate crisis and water scarcity that challenges the core business viability of the coal industry. However, despite the authority of the IPCC, Stern Report and many other studies and reports, climate change science has not yet become part of the bureaucratic-legal framework of state governmental environmental planning and the minutiae of mine approvals, and there are powerful interests that work to prevent it doing so. So far, the opponents of the Bickham coalmine have been successful, even if core arguments focussed on environmental ethics have remained marginalised in the debates. Contests waged in the domain of scientific discourse 
and regulatory regimes that are defined by government and powerful industries are rarely successful. But the fluidity of water, its ability to metamorphose from one form to another (e.g. from mist, to rain, to river, to sea) is an apt metaphor for the impetus for community and environmentalist opponents to endure and eventually prevail in mining conflicts and perhaps even for a sea-change in mining policy.

\section{NOTES}

1. The Greens Party is a relatively minor political party that contests elections against candidates from the currently dominant Liberal and Labor Parties. As their name suggests, the Greens Party members campaign heavily on environmental issues.

2. For example, in February 2007 it was reported that $13 \%$ of one large mining company's workforce of 800 live in the Murrurundi area. (See Herald,Newcastle, 5 February 2007, p.17)

3. Creation being who moved across the land, helping develop the landscape and giving life and law to man and other aspects of the environment, (Source: Aboriginal Hunter, http://www.arwarbukarl.com.au/Default.aspx).

4. Overburden is a term used to describe excess crushed rock and soil dug out of an open cut mine, which is piled into mounds called 'overburden dumps' to create artificial landforms which are then revegetated.

5. The latter refers to the possibility that, if Australia does not supply resource hungry countries with energy requirements, Australia's security might be threatened (e.g., Japan entering WWII after being denied resources).

\section{REFERENCES}

AUSTRALIAN BROADCASTING CORPORATION. 2003. DIY Dissent. In ABC Stateline NSW (Online). Sydney, 19 September.

AUSTRALIAN BROADCASTING CORPORATION. 2004. DNR waters down mine concerns. In ABC News (Online), Sydney, February 16.

AUSTRALIAN BROADCASTING CORPORATION. 2006. Consultants reject huge mine expansion rumours. In ABC News (Online), Sydney, May 15.

ADAMS, M. 2004. Big dig from tonnes of coal starts. In The Northern Daily Leader. Tamworth, 16 July.

ADAMS, P. 2004. Pages is not a closed book. In The Weekend Australian Magazine, 10-11 January, p.9.

ALBRECHT, G. 2000. Rediscovering the Coquun: Towards an environmental history of the Hunter River. Presented at: Our river: Our Future - Water Forum 2000 Proceedings, Wyndham Estate Branxton, pp.4-26.

2005. Solastalgia: A new concept in human health and identity. Philosophy Activism Nature 3: 41-55.

ALBRECHT, G., G. SARTORE, L. CONNOR, N. HIGGINBOTHAM, S. FREEMAN. 2007. Solastalgia: The distress caused by environmental change. Australasian Psychiatry 15 (S1) S 95-98..

BENNETTO, P. 2006. Bickham underground has tensions surfacing. In Herald, Newcastle, 25 October, p.9.

BROSIUS, J. P. 1999. Anthropological engagements with environmentalism. Current Anthropology 40: 277-309

CONNOR L., G. ALBRECHT, N. HIGGINBOTHAM, S. FREEMAN, W. SMITH. 2004. Environmental Change and Human Health in Upper Hunter Communities of New South Wales. EcoHealth 1: 47-58.

CRC Mining. 2006. Australian Mining Technology Conference, Cypress Lakes Resort, Hunter Valley, 26-27 September (Advertisement). http://www.crcmining.com.au/dynamic_page.php?page_reset=1\&page_id=53 Accessed 12 Sept 2006

HERALD. 2004. River to undergo impact study as company samples the coal. In Herald, Newcastle, 20 January, p.6 (author not named).

2006. Recycled water will be a first: Not a drop to waste as town introduces bans. In Herald, Newcastle, 27 May, p.28 (author not named).

HIGGINBOTHAM, N., L. CONNOR, G. ALBRECHT G, S. FREEMAN, K. AGHO. 2006. Validation of an Environmental Distress Scale. EcoHealth 3: 245-54.

INTERGOVERNMENTAL PANEL ON CLIMATE CHANGE (IPCC). 2007. Fourth Assessment Report: Climate Change 2007. http://www.ipcc.ch/activity/ar.htm Accessed 5 February.

McCARTHY, J. 2006. Left high and dry. In Herald, Newcastle, May 27, pp.4-5.

2007. Industrial strength. In Herald, Newcastle. Newcastle, 24 February, pp.H2.

NEWELL, P. 2003. The River. Camberwell, Vic.: Penguin.

2005. River runs deep with environmental concerns. In Herald, Newcastle, 26 March, p.19.

2006. Creating community through conflict: How environmental issues can bring town and country together. In Hunter Valley Research Foundation 2006 Lecture Series: lecture 2, 30 August. Newcastle: Hunter Valley Research Foundation.

NSW DEPARTMENT OF MINERAL RESOURCES. 2004. Assessment Report: Review of Environmental Factors. Proposed Bulk Sample by Bickham Coal Company Pty Ltd within Exploration Licence 5306. pp.1-3.

NSW DEPARTMENT OF PLANNING. 2005. Coalmining Potential in the Upper Hunter Valley - Strategic Assessment. Sydney: NSW Department of Planning. 
NSW DEPT. OF PRIMARY INDUSTRIES (MINERALS). 2004. Bickham coal bulk sample approved (Media release 28 Jan 2004). http://www.minerals.nsw.gov.au/MediaReleases/23/21-11-03. Accessed 30 January 2005.

NSW LEGISLATIVE COUNCIL. 2003. Bickham Coalmine Proposal. In NSW Legislative Council Hansard, 27 May.http://www.anzacatt.org.au/prod/parlment/hansart.nsf/V3key/LC20030527033 Accessed 30 August.

NSW MINERALS COUNCIL LTD. 2007. The Other Side: Brought to You by Mining: Media Release. 19 February 2007. Sydney

NSW MINERALS COUNCIL LTD, AUSTRALIAN COAL ASSOCIATION. 2007. Joint Statement: \$400 million Commitment to Low Emissions Coal Technologies in NSW (Media Release 27 June 2007). http://www.australiancoal.com.au/Pubs/NSW\%20Coal\%2021\%20Fund\%20Announcement\%2027\%20June\%202007.pdf Accessed 25 Oct 2007.

O'NEILL M. 2006. Halting Anvil Hill doesn't save the world one bit. In Herald, Newcastle, 30 November, p.11.

2007. To mine or not to mine: No coal helps no one, more research helps all. In Herald, Newcastle, 22 February, p.9.

PALSSON, G. 1996. Human-environmental relations: Orientalism, paternalism and communalism. In Nature and Society: Anthropological Perspectives, P. Descola, and G. Palsson (eds.). London: Routledge, pp.63-81.

PARSONS BRINKERHOFF. 2006a. Bickham Coal Mine: Water Resource Assessment (update October 2006). http://www.bickhamcoal.com.au/files/BC_News_Oct06.pdf Accessed 28 August 2007.

2006b. Bickham Coal Project: Water Resources Assessment and Community Consultation Briefing Paper, May. Sydney: Parsons Brinkerhoff.

PEATLING, S. 2002. Parched town's fears for thirsty mining plan. In Sydney Morning Herald, November 23-4, p.6.

QUINN, B. 2005. Beyond the shadow of a drought. In Herald, Newcastle, 26 March, p.3.

RESERVE BANK OF AUSTRALIA. 2007. Statement on Monetary Policy - February 2007: Commodity prices and Australia's terms of trade. http://www.rba.gov.au/PublicationsAndResearch/StatementsOnMonetaryPolicy/Feb2007/international_economic_developments.html Accessed 3 September 2007.

RICHARDS, J. 2005. Model of coalmine water impact flawed. In Herald. Newcastle, 18 March, p.6.

STERN, N. 2006. Stern Review on the Economics of Climate Change 30 October 2006). London: HM Treasury http://www.hm-treasury.gov.uk/independent_reviews/stern_review_economics_climate_change/sternreview_summary.cfm Accessed 30 Nov 2006

STRANG, V. 2004. The Meaning of Water. Oxford: Berg

STUTSEL, ML. 2003. From Rhetoric to Relevance - the Australian Minerals Industry Sustainable Development Code. Canberra: Minerals Council of Australia. http://chamberofmines.co.za/UpcomingEvents/SusDevRep.pdf Accessed 4 Oct 2005.

THOMPSON, F. 2004a. Miner starts blasting to find coal seam. In Herald, Newcastle, 30 June, p. 23.

2004b. River not in peril: coal firm. In Herald, Newcastle, 11 December, p.16.

2005. Echoes of the past: Homestead grew on wool fortunes. In Herald, Newcastle, 22 March, p.15.

2006. Farmers say mines' thirst being put first. In Herald, Newcastle, 30 August, p.5.

2007. Dispute over pit clean-up. In Herald, Newcastle, 22 February, p.20.

TRIGGER, D.S. 1997. Mining, landscape and the culture of ideology in Australia. Ecumene 4: 161-80.

UPPER HUNTER SHIRE COUNCIL. 2006. Draft Upper Hunter Situation Analysis (November 2006) Newcastle: Planning Workshop Australia, pp.1-141.

2007. Level 4 water restrictions for Murrurundi. http://upperhunter.local-e.nsw.gov.au/news/pages/2335.html Accessed 26 February 2007.

VEALE, S. 2001. Remembering Country: History and Memories of Towarri National Park. Sydney: NSW National Parks and Wildlife Service, pp.1-98.

WEBB MCKEOWN and ASSOCIATES Pty Ltd. 2002. Flooding \& Surface Water Assessment for the Proposed Bulk Sample Development Application Proposed Bickham Coal Mine. Sydney http://www.bcag.com.au.

WILLIAMS, N. 2007. Now's not time to let coal boom pass us by. Herald, Newcastle, 9 July, p.9.

WILSON-MILlER, J. 2005. Conflict in the Valley: The Triumph of the Wonnarua. Sydney http://www.aare.edu.au/05pap/wil05317.pdf Accessed 6 March 2007: Self-Concept Enhancement and Learning Facilitation Research Centre, University of Western Sydney.

WYNHAUSEN, E. 2003. Action group to the coalface to block mine. In Weekend Australian, 11 January, p.5.

YOUNG, D. 2006. Water as Country on the Pitjantjatjara Yankunytjatjara Lands South Australia. Worldviews 10: 239-58. 